\title{
Bullfrog (Lithobates catesbeianus) farming system: water quality and environmental changes
}

Sistema de criação de rã-touro (Lithobates catesbeianus): qualidade da água e mudanças ambientais

Cacilda Thais Janson Mercante ${ }^{1}$, André Martins Vaz-dos-Santos², Munique de Almeida Bispo

Moraes $^{3}$, Jeniffer Sati Pereira ${ }^{4}$ and Júlio Vicente Lombardi ${ }^{1}$

${ }^{1}$ Centro de Pesquisa e Desenvolvimento Especializado em Recursos Hídricos, Instituto de Pesca, Avenida Francisco Matarazzo, 455, CEP 05001-900, São Paulo, SP, Brazil

e-mail: cthais@pesca.sp.gov.br; lombardi@pesca.sp.gov.br

${ }^{2}$ Laboratório de Esclerocronologia, Universidade Federal do Paraná - UFPR,

Rua Pioneiro, 2153, CEP 85950-000, Palotina, PR, Brazil

e-mail: andrevaz@ufpr.br

${ }^{3}$ Programa de Pós-Graduação em Aquicultura e Pesca, Centro de Pesquisa e Desenvolvimento

Especializado em Recursos Hídricos, Instituto de Pesca,

Avenida Francisco Matarazzo, 455, CEP 05001-900, São Paulo, SP, Brazil

e-mail: muniquebio@gmail.com

${ }^{4}$ Programa de Pós-Graduação em Ciências Biológicas, Universidade Estadual Paulista

"Júlio de Mesquita Filho" - UNESP, Avenida 24 A, 1515, CEP 13506-900, Rio Claro, SP, Brazil e-mail: jeniffer_pereira@yahoo.com.br

\begin{abstract}
Introduction: Frog farming, if not well managed, may cause environmental damages. The use of antibiotics, the organic discharge and the introduction of exotic species can disseminate risks such as eutrophication, changes in the water quality and organic pollution, factors that affect the human consumption. Aim: Evaluating the water quality of a bullfrog farming system, discussing their relations to production and the environment based on the current legislation. Methods: Sampling was performed on a monthly basis from November 2006 to March 2007 during growth and fattening phases of bullfrog (Lithobates catesbeianus). Sample sites were distributed according to the water flow: upstream from the mixing zone, affluent (supply water), bay, effluent, mixing zone and downstream from the mixing zone. In the field, $\mathrm{pH}$, electrical conductivity, dissolved oxygen, temperature and turbidity were measured. In laboratory, nitrogen, phosphorus and chlorophyll $a$ concentrations were analyzed. Results: The concentration of nutrients was determiner for water quality in the bay and its effluent. According to the current legislation, the effluent exceeded the limits for total phosphorus $\left(>0.030 \mathrm{mg} \mathrm{L}^{-1}\right)$ and total nitrogen $\left(>1.27 \mathrm{mg} \mathrm{L}^{-1}\right)$. Other variables presented acceptable values in light of the current laws. Conclusion: The high values of nutrients and other factors such as conductivity and turbidity are proportional to the animal growth due to the inadequate management practices evidenced by feed conversion rate. The following management options are proposed: maintaining the flow and decreased density of animals; maintaining the flow and density storage with adequate control of the food supply.
\end{abstract}

Keywords: management, aquaculture, phosphorus, nitrogen, effluent.

Resumo: Introduçáo: O cultivo de râs, se não bem manejado, pode causar danos ambientais. Uso de antibióticos, descarga orgânica e introdução de espécies exóticas podem promover eutrofização, alteração das águas e poluição orgânica afetando o consumo humano. Objetivo: Avaliar a qualidade da água de sistema de criação de rã-touro discutindo sobre sua relação com a produção e o meio ambiente baseado na legislação vigente. Métodos: As amostragens foram mensais de novembro/2006 a março/2007, abrangendo as fases de crescimento e engorda de rã touro Lithobates catesbeianus. Os locais de amostragem foram de acordo com o fluxo hídrico: a montante da zona de mistura, afluente (abastecimento), baia de criaçáo, efluente, zona de mistura e a sua jusante. No campo, foram medidos os valores de $\mathrm{pH}$, condutividade elétrica, oxigênio dissolvido, temperatura e turbidez. No laboratório foram analisadas as séries de nitrogênio e fósforo bem como a clorofila $a$. Resultados: A concentraçáo de nutrientes foi determinante da qualidade da água da baia e de seu efluente. Com relação à legislaçáo vigente, o efluente excedeu os limites estabelecidos para fósforo total $\left(>0,030 \mathrm{mg} \mathrm{L}^{-1}\right)$ e nitrogênio total 
(> 1,27 $\mathrm{mg} \mathrm{L}^{-1}$ ). Conclusão: Elevados valores de nutrientes e de outros fatores como condutividade e turbidez foram proporcionais ao crescimento dos animais podendo ser relacionadas às práticas de manejo inadequadas evidenciadas pela taxa de conversão alimentar. As seguintes alternativas de manejo são propostas: manutenção da vazão e diminuição da densidade de animais; manutençáo da vazão e da densidade de estocagem com controle adequado da oferta de alimento.

Palavras-chave: manejo, aquicultura, fósforo, nitrogênio, efluente.

\section{Introduction}

Over the last decades, several studies have been conducted aiming the improvement of the bullfrogs' production (Lithobates catesbeianus). The analyzed aspects are related to nutritional value, economic viability of commercial food, effects of toxicity, biochemistry and physiology of the species, pathologies and treatments, growth rate and molecular biology (Olvera-Novoa et al., 2007; França et al., 2008; Najiah et al., 2009; Pasteris et al., 2011; Castro et al., 2012; Mendonza et al., 2012).

According to FAO (2009), as any other aquaculture activity, frog farming may cause environmental damages if not well managed. Factors such as organic discharge, use of antibiotics, introduction of exotic species, among others can disseminate risks such as eutrophication, changes in the water quality and organic pollution, affecting human consumption. This organization proposes mitigation strategies such as effluent treatment, its reuse in agriculture and the use of low-polluting food. As stated by FAO (2009) likewise, it is necessary the development of specific rules for frog farming, since it is an important activity in many regions. These rules should be based on general principles of the "Code of Conduct for Responsible Fisheries", articles 9 and 9.1.3 (FAO, 1995), that recommends that each State should elaborate and regulate aquaculture development strategies as a requirement to ensure its ecological sustainability, allowing the rational use of resources in different applications.

In Brazil, the interest in bullfrog L. catesbeianus farming is growing because of the taste and texture of the meat, making it a great potential in aquaculture (França et al., 2008; Sipaúba-Tavares, 2008).

However, research focused on environmental issues and water quality in aquaculture is scarce not only in Brazil, but worldwide, particularly in bullfrog farming. Borges et al. (2012) is the only study in Brazil about discharge of bullfrogs farming effluents. Nevertheless, it is possible to find some studies dealing with the issue indirectly, for example the use of fertilizers in agriculture as a cause for amphibians decline in natural systems (Hamer et al., 2004).

Bishop et al. (1999) proposed that high nitrogen and phosphorus concentrations might affect the population and the community structure because the amphibians make use of water for reproduction. These authors demonstrated that exposure to nitrates can alter the feeding activity, mobility and reduce the growth and development processes of amphibian larvae. Flores-Nava (2000) reported some limnological parameters in water bodies at Yucatan City, Mexico, appropriate for growth of tadpoles and frogs and Flores-Nava et al. (1994) compared the water circulation arrangement in the cultivation of these animals. Benitez-Mandujano and Flores-Nava (1997) monitored the water quality in experiments that compared growth and metamorphosis. These authors observed that the phytoplankton primary productivity was essential to the tadpoles' growth since it accelerated the metamorphosis.

Sipaúba-Tavares (2008) in a study on feeding behavior and water quality in bullfrog tadpoles nurseries concluded that the use of diet, supplemented or not with plankton, provided satisfactory development, but with high nutrients concentrations and reduction of oxygen dissolved at the same time. Concerning this theme, it is important to promote studies to provide further information about water quality in bullfrog farming system. In addition, the description of environmental changes generated by the activity is also fundamental for sustainable management practices.

Considering the statements above and the principles mentioned in the Code of Conduct for Responsible Fisheries, this paper aimed the investigation of the water quality of a bullfrog farming system, discussing their relations with the production and the environment based on the current legislation. For comparisons, it was adopted the referential values of CONAMA Resolution $357 / 2005$, which includes the acceptable limits of 
various parameters of water quality and recommends the treatment of effluents.

\section{Material and Methods}

Sampling were performed in a commercial bullfrog farming system, located in Tremembé (São Paulo) in tropical region, $22^{\circ} 57^{\prime} 40^{\prime \prime} \mathrm{S}, 45^{\circ} 32^{\prime} 24^{\prime \prime}$ W, running since 1997.

In the bullfrog farming was used the "amphifarm" system. The bay $\left(12 \mathrm{~m}^{2}\right)$ analyzed during of sampling had an average of 700 individuals (average density of 58 bullfrogs $\mathrm{m}^{-2}$ ), being the water constantly renewed in the system on an average flow input and output of $0.064^{\circ} \mathrm{L}^{\circ} \mathrm{s}^{-1}$. It was used extruded feed for fish with $40 \%$ crude protein, indicated for carnivorous species.

Water samples were collected during five months, November 2006 until March 2007, comprising the stages of initial-fattening $\left(7^{\circ} \mathrm{g}\right)$ (November, December and January) and fattening $\left(200^{\circ} \mathrm{g}\right)$ (February and March). A creek headwater was dammed, supplying the water for the bullfrog farming system. Sampling activities included the following sites: Site 1 - Upstream $\left(16^{\circ} \mathrm{m}\right)$ from the mixing zone (selected by the logistic position); Site 2 - Affluent (bay supply source); Site 3 - Breeding bay; Site 4 - Effluent (water outflow from the bay); Site 5 - Mixing zone (effluent discharge site into the receiving water body); and Site 6 - Downstream (24 $\mathrm{m})$ from the mixing zone (Figure 1).

The following variables were measured (in situ) on a monthly basis at each site with multiparameter probe Horiba U-22 model: pH, conductivity, dissolved oxygen, temperature, turbidity. In the laboratory, the total suspended solids, alkalinity and total hardness were analyzed by titulometric method (APHA, 2005). The concentrations of total nitrogen (TN) and total phosphorus (TP) were determined according to Valderrama (1981) and orthophosphate $\left(\mathrm{P}-\mathrm{PO}_{4}\right)$ according to Strickland and Parsons (1960). Chlorophyll $a$ was estimated following Sartory and Grobellar (1984). Total ammoniac nitrogen (TAN) concentration was estimated by Nessler method (APHA, 2005), nitrate by cadmium reduction method (APHA, 2005) and the nitrite by the method described by Griess modified (Giné et al., 1980). All of them were determined using a spectrophotometer.

The nutrient load was determined by the product of the values of flow $\left(\mathrm{L}^{\circ} \mathrm{s}^{-1}\right)$ and concentrations of total phosphorus (TP) using the formula (1):

$\mathrm{C}=[\mathrm{N}] * \mathrm{Q}$

Which $\mathrm{C}=$ nutrients load; $[\mathrm{N}]=$ nutrient concentrations and $\mathrm{Q}=$ flow rate of each treatment. The results were expressed in grams per day $\left(\mathrm{g}^{\mathrm{o}} \mathrm{day}^{-1}\right)$.

In order to characterize the zootechnical cycle environmental variables were described in terms of average value and confidence interval of $95 \%$, both for sites and months. Whenever possible these means were compared with referential values defined by CONAMA resolution 357/2005. Temporal and site variations on the variables were analyzed through an ANOVA two-way without replication after $\log (\mathrm{x}+1)$ transformation, followed by a Tukey test (Sokal and Rohlf, 1995). The level of significance adopted was 0.05 .

\section{Results}

Spatio-temporal analysis showed different pattern among variable analyzed. Significant

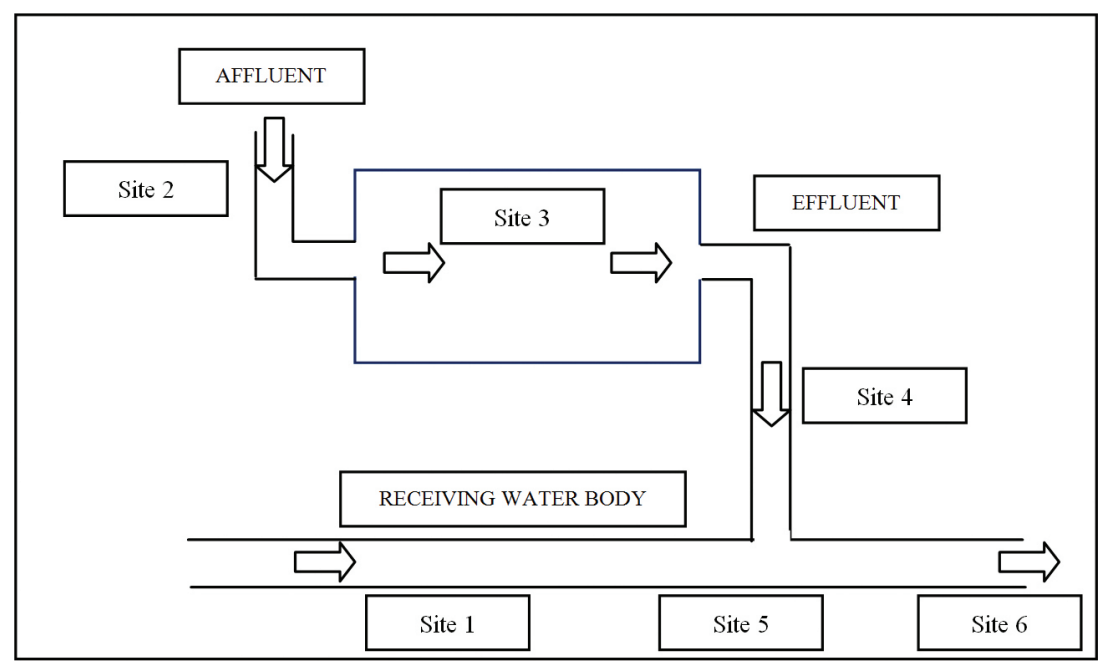

Figure 1. Representation of sampling sites in bullfrog farming system in Tremembé, São Paulo. 


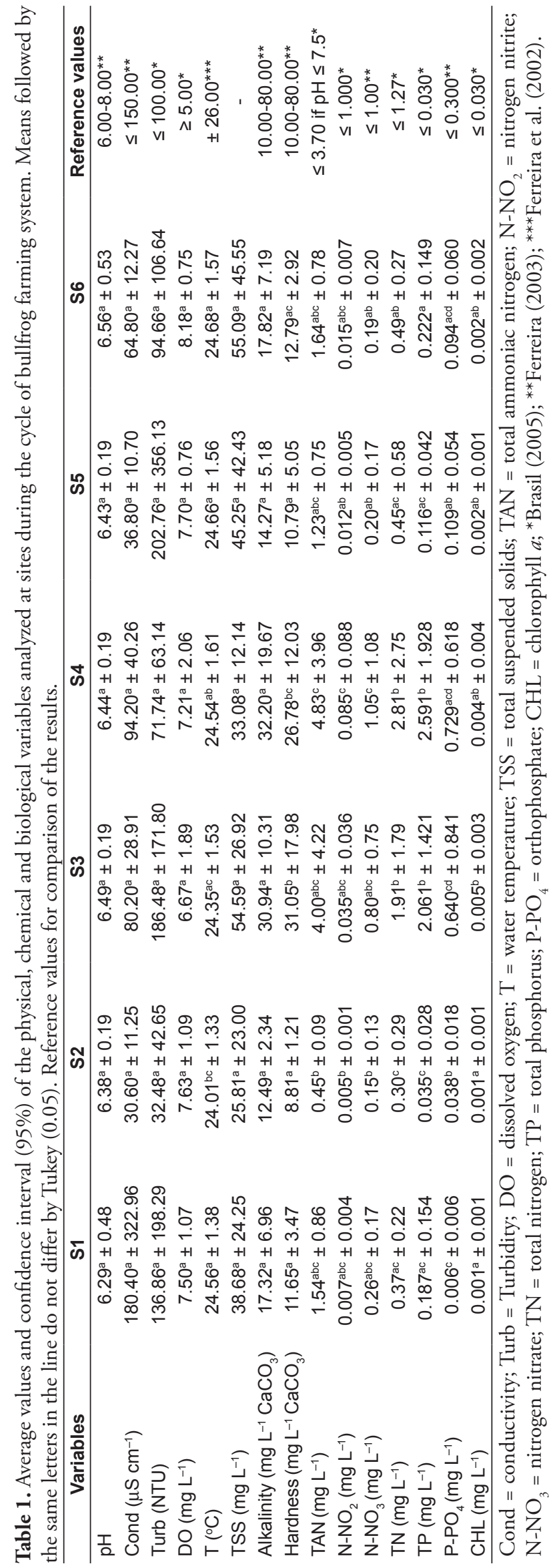


variations among sites were found in water temperature $(\mathrm{F}=4.47 ; \mathrm{P}=0.007)$, hardness $(\mathrm{F}=8.46 ; \mathrm{P}<0.001)$, total ammoniac nitrogen $(\mathrm{F}=3.08 ; \mathrm{P}=0.032)$, nitrite $(\mathrm{F}=4.94 ; \mathrm{P}=0.004)$, nitrate $(\mathrm{F}=4.65 ; \mathrm{P}=0.006)$, total nitrogen $(\mathrm{F}=10.49 ; \mathrm{P}<0.001)$, total phosphorus $(\mathrm{F}=16.93$; $\mathrm{P}<0.001)$, orthophosphate $(\mathrm{F}=14.27 ; \mathrm{P}<0.001)$ and chlorophyll $a(\mathrm{~F}=3.73 ; \mathrm{P}=0.015)$ (Table 1). Among months, $\mathrm{pH}(\mathrm{F}=4.98 ; \mathrm{P}=0.006)$, conductivity $(\mathrm{F}=3.02 ; \mathrm{P}=0.042)$, turbidity $(\mathrm{F}=5.90 ; \mathrm{P}=0.003)$, dissolved oxygen $(\mathrm{F}=2.93$; $\mathrm{P}=0.047)$, water temperature $(\mathrm{F}=189.37 ; \mathrm{P}<$ $0.001)$, total suspended solids $(\mathrm{F}=5.60 ; \mathrm{P}=0.003)$, nitrate $(\mathrm{F}=4.62 ; \mathrm{P}=0.008)$ and total nitrogen $(\mathrm{F}=28.56 ; \mathrm{P}<0.001)$ presented significant differences (Table 2).

Considering the current legislation CONAMA resolution 357/2005 (Brasil, 2005) (Class II, lentic environment), nutrient concentrations in effluent (Site 4) resulted in very large values, much higher than it is recommended. The maximum concentration recommended for total phosphorus in effluent is $0.030 \mathrm{mg} \mathrm{L}^{-1}$. However, in this study the values obtained ranged from $0.26 \mathrm{mg} \mathrm{L}^{-1}$ (November $16^{\text {th }}, 2006$ ) to $5.0 \mathrm{mg} \mathrm{L}^{-1}$ (February $\left.15^{\text {th }}, 2007\right)$. The total nitrogen concentrations in effluent were between $0.18 \mathrm{mg} \mathrm{L}^{-1}$ (November $\left.16^{\text {th }}, 2006\right)$ and $6.11 \mathrm{mg} \mathrm{L}^{-1}$ (February $\left.15^{\text {th }}, 2007\right)$, in accordance with CONAMA, whose maximum acceptable value is $1.27 \mathrm{mg} \mathrm{L}^{-1}$ (Table 1).

The average concentrations of total phosphorus (TP) and flow in the water (inlet and outlet) and the load produced per day were compared between different systems of animals' production (Table 3).

Table 2. Average values and confidence interval (95\%) of the physical, chemical and biological variables analyzed monthly during the cycle of bullfrog farming system. Means followed by the same letters in the line do not differ by Tukey (0.05).

\begin{tabular}{|c|c|c|c|c|c|}
\hline Variables & November 2006 & December 2006 & January 2007 & February 2007 & March 2007 \\
\hline $\mathrm{pH}$ & $6.33^{a b} \pm 0.32$ & $6.34^{\mathrm{ab}} \pm 0.08$ & $6.13^{a} \pm 0.10$ & $6.70^{b} \pm 0.24$ & $6.66^{b} \pm 0.15$ \\
\hline Conductivity $\left(\mu \mathrm{S} \mathrm{cm}^{-1}\right)$ & $52.50^{\mathrm{ab}} \pm 9.69$ & $38.50^{\mathrm{a}} \pm 18.52$ & $56.50^{\mathrm{ab}} \pm 32.96$ & $61.17^{\mathrm{ab}} \pm 30.25$ & $197.17^{b} \pm 225.94$ \\
\hline Turbidity (NTU) & $36.72^{\mathrm{ab}} \pm 20.59$ & $16.30^{\mathrm{a}} \pm 4.56$ & $144.78^{b} \pm 71.70$ & $105.57^{\mathrm{ab}} \pm 130.37$ & $300.78^{b} \pm 256.52$ \\
\hline $\mathrm{DO}\left(\mathrm{mg} \mathrm{L}^{-1}\right)$ & $7.11^{\mathrm{ab}} \pm 0.63$ & $7.20^{\mathrm{ab}} \pm 1.23$ & $8.58^{a} \pm 0.47$ & $6.41^{b} \pm 1.41$ & $8.11^{\mathrm{ab}} \pm 0.70$ \\
\hline $\mathrm{T}\left({ }^{\circ} \mathrm{C}\right)$ & $23.72^{a} \pm 0.31$ & $24.65^{c} \pm 0.14$ & $22.73^{b} \pm 0.28$ & $24.43^{c} \pm 0.07$ & $26.82^{d} \pm 0.44$ \\
\hline TSS (mg L-1) & $55.72^{\mathrm{ab}} \pm 27.75$ & $29.83^{\mathrm{a}} \pm 20.89$ & $76.76^{b} \pm 25.98$ & $23.54^{a} \pm 1.81$ & $24.57^{a} \pm 2.27$ \\
\hline $\begin{array}{l}\text { Alkalinity } \\
\left(\mathrm{mg} \mathrm{L}^{-1} \mathrm{CaCO}_{3}\right)\end{array}$ & $24.23^{a} \pm 4.55$ & $19.31^{a} \pm 2.99$ & $22.67^{a} \pm 16.09$ & $23.57^{a} \pm 14.49$ & $14.42^{a} \pm 4.30$ \\
\hline $\begin{array}{l}\text { Hardness } \\
\left(\mathrm{mg} \mathrm{L}^{-1} \mathrm{CaCO}_{3}\right)\end{array}$ & $15.51^{a} \pm 3.53$ & $9.57^{a} \pm 1.56$ & $21.12^{\mathrm{a}} \pm 13.39$ & $16.83^{a} \pm 9.44$ & $21.87^{a} \pm 14.17$ \\
\hline TAN $\left(\mathrm{mg} \mathrm{L}^{-1}\right)$ & $1.67^{a} \pm 0.75$ & $0.54^{a} \pm 0.06$ & $3.24^{a} \pm 2.80$ & $3.96^{a} \pm 3.59$ & $1.98^{\mathrm{a}} \pm 1.24$ \\
\hline $\mathrm{N}-\mathrm{NO}_{2}\left(\mathrm{mg} \mathrm{L}^{-1}\right)$ & $0.013^{a} \pm 0.004$ & $0.010^{\mathrm{a}} \pm 0.004$ & $0.039^{a} \pm 0.036$ & $0.059^{a} \pm 0.071$ & $0.016^{a} \pm 0.021$ \\
\hline $\mathrm{N}-\mathrm{NO}_{3}\left(\mathrm{mg} \mathrm{L}^{-1}\right)$ & $0.30^{\mathrm{ab}} \pm 0.11$ & $0.15^{a} \pm 0.12$ & $0.13^{a} \pm 0.08$ & $0.94^{b} \pm 0.94$ & $0.68^{\mathrm{ab}} \pm 0.41$ \\
\hline $\mathrm{TN}\left(\mathrm{mg} \mathrm{L}^{-1}\right)$ & $0.17^{a} \pm 0.07$ & $0.16^{a} \pm 0.07$ & $1.83^{\mathrm{b}} \pm 1.80$ & $2.18^{b} \pm 1.84$ & $0.95^{b} \pm 0.53$ \\
\hline $\mathrm{TP}\left(\mathrm{mg} \mathrm{L}^{-1}\right)$ & $0.304^{a} \pm 0.161$ & $0.826^{a} \pm 0.962$ & $1.261^{\mathrm{a}} \pm 1.388$ & $1.495^{\mathrm{a}} \pm 1.778$ & $0.459^{\mathrm{a}} \pm 0.657$ \\
\hline $\mathrm{P}_{-} \mathrm{PO}_{4}\left(\mathrm{mg} \mathrm{L}^{-1}\right)$ & $0.099^{a} \pm 0.046$ & $0.063^{a} \pm 0.040$ & $0.352^{\mathrm{a}} \pm 0.498$ & $0.307^{a} \pm 0.304$ & $0.525^{\mathrm{a}} \pm 0.684$ \\
\hline $\mathrm{CHL}\left(\mathrm{mg} \mathrm{L}^{-1}\right)$ & $0.002^{\mathrm{a}} \pm 0.002$ & $0.001^{a} \pm 0.001$ & $0.003^{a} \pm 0.001$ & $0.005^{\mathrm{a}} \pm 0.004$ & $0.002^{\mathrm{a}} \pm 0.002$ \\
\hline
\end{tabular}

$\mathrm{DO}=$ dissolved oxygen; $\mathrm{T}=$ water temperature; TSS $=$ total suspended solids; TAN = total ammoniac nitrogen; $\mathrm{N}-\mathrm{NO}_{2}=$ nitrogen nitrite; $\mathrm{N}-\mathrm{NO}_{3}=$ nitrogen nitrate; $\mathrm{TN}=$ total nitrogen; $\mathrm{TP}=$ total phosphorus; $\mathrm{P}-\mathrm{PO}_{4}=$ or thophosphate; $\mathrm{CHL}=$ chlorophyll $a$.

Table 3. Average concentrations of total phosphorus (TP) and flow in the water (inlet and outlet) and the load produced per day in different systems of animals' production.

\begin{tabular}{cccccccc}
\hline & \multicolumn{3}{c}{ Inlet } & \multicolumn{3}{c}{ Outlet } & \\
\cline { 2 - 5 } & $\begin{array}{c}\text { Concentration } \\
\left(\mathbf{m g ~ L}^{-1}\right)\end{array}$ & $\begin{array}{c}\text { Flow } \\
\left(\mathbf{L ~ s}^{-1}\right)\end{array}$ & $\begin{array}{c}\text { Load } \\
\left(\mathbf{g ~ d i a}^{-1}\right)\end{array}$ & $\begin{array}{c}\text { Concentration } \\
\left(\mathbf{m g ~ L}^{-1}\right)\end{array}$ & $\begin{array}{c}\text { Flow } \\
\left(\mathbf{L ~ s}^{-1}\right)\end{array}$ & $\begin{array}{c}\text { Load } \\
\left(\mathbf{g ~ d i a}^{-1}\right)\end{array}$ & This study \\
\hline $\begin{array}{c}\text { Bullfrog } \\
\text { farming }\end{array}$ & 0.03 & 0.06 & 0.21 & 0.19 & 0.06 & 14.30 & Borges et al. (2012) \\
$\begin{array}{c}\text { Bullfrog } \\
\text { farming }\end{array}$ & 0.07 & 0.03 & 0.18 & 6.09 & 0.02 & 11.57 & Pereira et al. (2008) \\
$\begin{array}{c}\text { Tilapia } \\
\text { farming } \\
\text { Trout } \\
\text { farming }\end{array}$ & 0.42 & 2.76 & 9.70 & 2.45 & 2.76 & 49.10 & Moraes et al. (2013) \\
\hline
\end{tabular}


The average productivity of the bullfrog farming system was $3.4 \mathrm{~kg}$ of meat of bullfrog $\mathrm{m}^{-2}$ and the feed conversion ratio was 5.31:1.

\section{Discussion}

Compared to the usual monitoring water quality parameters for production, the results demonstrated acceptable values of $\mathrm{pH}$, dissolved oxygen, water temperature, alkalinity and hardness respectively.

The lower values of $\mathrm{pH}$ during the production cycle were, probably, due to the decomposition process of organic matter, corroborated by the values of conductivity. Other authors (Seixas-Filho et al., 2011; Borges et al., 2012) have observed the same situation. The $\mathrm{pH}$ remained mildly acidic, being it an optimum condition for frogs (Ferreira, 2003). Additionally, Sipaúba-Tavares et al. (2008) suggested a $\mathrm{pH}$ range between 6.5 to 7.0 , but observed values of 6.0 to 8.0 without harm to animals.

High electrical conductivity values and turbidity were observed, especially at the end of the fattening period. These parameters are directly related to the input of food into the water that promotes an increase of ions and suspended particles (Tacon and Foster, 2003; Baccarin and Camargo, 2005).

The highest values of total suspended solids were observed in the river, $119 \mathrm{mg} \mathrm{L}^{-1}$ and 116 $\mathrm{mg} \mathrm{L}^{-1}$ upstream (Site 1) and downstream (Site 6), respectively, during January, probably due to the carrying of inorganic and organic particles related to rainy season.

Regarding the turbidity, high values were obtained upstream (Site 1), in the bay (Site 3) and in mixing zone (Site 5) in the last three months. According to the criterion of CONAMA Resolution 357/2005 (Brasil, 2005), values up to $100 \mathrm{NTU}$ are acceptable, indicating that the results in these sites were not in accordance with the legislation. The stream catchment crossed a landfill that may have caused the high values obtained upstream. Sipaúba-Tavares (1994) discusses that high levels of turbidity may also be related to the presence of clays, colloidal or dissolved organic matter.

CONAMA Resolution 357/2005 (Brasil, 2005) recommends that the minimum limit for dissolved oxygen is $5 \mathrm{mg} \mathrm{L}^{-1}$. The values during the production cycle were acceptable, probably due to the fact that the bullfrog in growing and fattening phases presents predominantly air breathing, addition to the maintenance the continuous water flow and high renewal rate in the bay.

The weight gain is influenced by environmental conditions since the metabolism of bullfrogs may vary according to the temperature, because frogs are poikilotherms (LIMA ET AL., 2003). Thus, the production of bullfrogs is performed during the warm season, in view of a better adaptation and development of the animals, at an average temperature of $26^{\circ} \mathrm{C}$ (Ferreira et al., 2002). The water temperature varied between $22^{\circ} \mathrm{C}$ and $27^{\circ} \mathrm{C}$ during the production cycle. The temporal variation observed was considered adequate and it is within the standards for production. In study of SipaúbaTavares et al. (2008) the average water temperature of the bullfrog farming system ranged from $24^{\circ} \mathrm{C}$ to $26{ }^{\circ} \mathrm{C}$, similar to the present study, providing adequate condition for the proper development of the animals.

The presence of calcium in the food composition had a direct relationship with the increase alkalinity and hardness verified in the breeding bay (Site 3 ) and in effluent (Site 4). Therefore, the feeding altered these values; however, the observed values remained within the values already observed (between 10 and $80 \mathrm{mg} \mathrm{L}^{-1} \mathrm{CaCO}_{3}$ ) without apparent damage throughout the production cycle (Ferreira, 2003).

In regard to nutrients, the values were significantly different among sites, with increased in the breeding bay (Site 3) and effluent (Site 4), with consequent dilution of concentrations in the mixing zone (Site 5) and downstream from mixing zone (Site 6).

Total ammoniac nitrogen values were higher than the acceptable levels for production described by Ferreira (2003), which may cause damage to animals when above $0.7 \mathrm{mg} \mathrm{L}^{-1}$. The increase observed in the breeding bay (Site 3 ) and in effluent (Site 4) was related to feeding and excretion corroborated by study performed by SeixasFilho et al. (2011), where treatments with feed showed higher concentrations of TAN compared to treatments without feed.

Benitez-Mandujano and Flores-Nava (1997) in experiments about growth and metamorphosis of Rana catesbeiana, obtained relative low values of nitrite, ranging from 0.08 to $0.10 \mathrm{mg} \mathrm{L}^{-1}$, higher than values obtained in the present study and within the interval recommended for production (Ferreira, 2003).

High values of nitrate, total nitrogen, total phosphorus and orthophosphate were obtained in the breeding bay (Site 3) and in effluent (Site 4). During the production cycle, an increase in the concentrations of TAN, N-NO $, \mathrm{N}_{2} \mathrm{NO}_{3}, \mathrm{TN}$, $\mathrm{TP}$ and $\mathrm{P}_{-} \mathrm{PO}_{4}$ were noted. High concentrations of nutrients in effluent are associated with feed 
management during grow-out phase that causes deterioration of the water quality (Borges et al., 2012), as the eutrophication process. Bullfrogs show better performance when fed with crude protein diets near $40 \%$ and carbohydrates, both for tadpoles (Stéfani et al., 2001) as in the fattening stage (Stéfani et al., 2002; Olvera-Novoa et al., 2007; Seixas-Filho et al., 2013), because the amphibians are carnivorous in post-metamorphic phase. Protein levels between 35 and $40 \%$ have a ratio of C:N smaller than 10:1 and are easily decomposed by bacteria. The large amount of decomposing organic matter by aerobic organisms reflects in a reduction of oxygen content in water (McIntosh, 2000), probably promoting the increase of nutrients.

According to FAO (2009), like in any other aquaculture activity, if not well managed it can cause several problems, mentioning organic discharges due to the excessive release of nutrients into the water, causing eutrophication and ecological changes.

During the period studied, the concentration of chlorophyll $a$ reached a maximum value of $11 \mu \mathrm{g}$ $\mathrm{L}^{-1}$, being the maximum value acceptable $30 \mu \mathrm{g} \mathrm{L}{ }^{-1}$ (Brasil, 2005). The constant renewal of water in the bay to removing excreta in the water and skin debris coming from the constant exchanges of animals (Ferreira et al., 2002) hindered the establishment of phytoplankton.

In this study, the increased flow resulted in higher loads of TP in comparison with Borges et al. (2012), who had the highest concentrations of this nutrient. The water inflow controlled in the production system directly reflects in the nutrient loads in effluent, fact also observed in tilapia and trout farming systems (Pereira et al., 2008; Moraes et al., 2013, respectively).

Considering the area of the bay and density of animals, the average productivity of bullfrogs $\left(3.40 \mathrm{~kg} \mathrm{~m}^{-2}\right)$ in "amphifarm" system was similar to Fontanello et al. (1993), who obtained a productivity of $3.86 \mathrm{~kg} \mathrm{~m}^{-2}$ with the lowest number of animals per area of production ( 50 bullfrogs $\mathrm{m}^{-2}$ ).

The bullfrog farming system showed high nitrogen and phosphorus concentrations coming from the excessive food and excreta of animals and according to the current legislation, this system is irregular with respect to the discharge of effluent with high nutrients concentrations, a potential inducer of the eutrophication process. It is important to note that this increase in nutrients and other factors such as conductivity and turbidity is proportional to the animal growth, due to the inadequate feeding management practices evidenced by feed conversion rate being possible to posit that a part of the feed was discharged in effluent.

A constant renovation of the water in the breeding bay is necessary to avoid the toxic effect for bullfrogs. However, it may promote higher loads of nutrients. To improve the quality of effluent aiming to reduce nutrient loading, besides treatment of effluent, are proposed the following management options: a) maintaining the flow and decreased density of animals; b) maintaining the flow and density storage with a better control of the food supply, its quality and digestibility.

\section{Acknowledgments}

To FAPESP for the financial support (Process 2005/05180-0). Authors express their gratitude to the reviewers of the manuscript.

\section{References}

American Public Health Association - APHA, American Water Works Association - AWWA and Water Pollution Control Federation - WPCF. 2005. Standard Methods for the examination of Water and Wastewater. 21th ed. Washington: APHA, AWWA, WPCF. 1085 p.

BACCARIN, AE. and CAMARGO, AFM. 2005. Characterization and evaluation of the feed management on the effluents of Nile tilapia (Oreochromis niloticus) culture. Brazilian Archives of Biology and Technology, vol. 48, no. 1, p. 81-90. http:// dx.doi.org/10.1590/S1516-89132005000100012

BERNITEZ-MANDUJANO, MA. and FLORESNAVA, A. 1997. Growth and metamorphosis of Rana catesbeiana (Shaw) tadpoles fed live and supplementary feed, using tilapia, Oreochromis niloticus (L.), as a biofertilizer. Aquaculture Research, vol. 28, no. 7, p. 481-488. http://dx.doi. org/10.1111/j.1365-2109.1997.tb01066.x

BISHOP, C., MAHONY, N., STRUGER, JNGP. and PETIT, K. 1999. Anuran development, density, and diversity in relation to agricultural activity in the Holland River watershed, Ontario, Canada (1990-1992). Environmental Monitoring Assessment, vol. 57, p. 21-43. http://dx.doi. org/10.1023/A:1005988611661

BORGES, FF., AMARAL, LA. and De STÉFANI, MV. 2012. Characterization of effluents from bullfrog (Lithobates catesbeianus, Shaw, 1802) grow-out ponds. Acta Limnologica Brasiliensia, vol. 24, no. 2, p. 160-166. http://dx.doi.org/10.1590/S2179975X2012005000035

Brasil. Ministério do Desenvolvimento Urbano e Meio Ambiente. Conselho Nacional do Meio Ambiente - CONAMA. 2005. Resolução no 357 , 
de 17 de março de 2005. Diário Oficial da República Federativa do Brasil, Brasília, DF, 18 mar. 2005.

CASTRO, CS., AGOSTINHO, CA., ARGENTIM, D., ALEXANDRE, JS., OLIVEIRA, LC., SOUSA, RMR. and PADILHA, PM. 2012. Feed digestibility and productive performance of bullfrogs fed in high and low frequency. Aquaculture, vol. 326329, p. 123-128. http://dx.doi.org/10.1016/j. aquaculture.2011.11.010

FERREIRA, CM., PIMENTA, AGC. and PAIVANETO, JS. 2002. Introdução à ranicultura. Boletim Técnico do Instituto de Pesca, vol. 33, p. 1-15.

FERREIRA, CM. 2003. A importância da água e sua utilização em ranários comerciais. Panorama da Aquicultura, vol. 13, no. 79, p. 15-17.

FLORES-NAVA, A., OLVERA-NOVOA, MA. and GASCA-LEYVA, E. 1994. A comparison of the effects of three water-circulation regimes on the aquaculture of bullfrog (Rana catesbeiana Shaw) tadpoles. Aquaculture, vol. 128, no. 1-2, p. 105-114. http://dx.doi.org/10.1016/0044-8486(94)90106-6

FLORES-NAVA, A. 2000. Bullfrog Rana catesbeiana farming in Latin America: an overview. World Aquaculture, vol. 31, no. 2, p. 22-29.

FONTANELLO, D., WIRZ, RR., ARRUDA-SOARES, H., FREITAS, EAN. and FERREIRA, CM. 1993. Comparaçáo de quatro sistemas de engorda de rãs-touro (Rana catesbeiana Shaw, 1802): tanque-ilha, confinamento, anfigranja e gaiolas, 1 - desenvolvimento ponderal; 2 - custo operacional. Boletim do Instituto de Pesca, vol. 20, p. 43-58.

FOOD AND AGRICULTURE ORGANIZATION OF THE UNITED NATION - FAO. 1995. Code of Conduct for Responsible Fisheries. FAO - Fisheries and Aquaculture Department: Rome. 41 p.

FOOD AND AGRICULTURE ORGANIZATION OF THE UNITED NATION - FAO. 2009. The State of World Fisheries and Aquaculture 2008. FAO - Fisheries and Aquaculture Department: Rome. 146 p.

FRANÇA, FM., DIAS, DC., TEIXEIRA, PC., MARCANTÔNIO, AS., DE STÉFANI, MV., ANTONUCCI, AM., ROCHA, G., RANZANIPAIVA, MJT. and FERREIRA, CM. 2008. Efeito do probiótico Bacillus subtilis no crescimento, sobrevivência e fisiologia de rás-touro (Rana catesbeiana). Boletim do Instituto de Pesca, vol. 34, no. 3, p. 403-412.

GINÉ, H., BERGAMIN, H., ZAGATTO, EAG. and REIS, BF. 1980. Simultaneous determination of nitrate and nitrite by flow injection analysis. Analytical Chemistry Acta, vol. 114, p. 191-197. http://dx.doi.org/10.1016/S0003-2670(01)84290-2

HAMER, AJ., MAKINGS, JA., LANE, SJ. and MAHONY, MJ. 2004. Amphibian decline and fertilizers used on agricultural land in south-eastern
Australia. Agriculture Ecosystems and Environment, vol. 102, no. 3, p. 299-305. http://dx.doi. org/10.1016/j.agee.2003.09.027

LIMA, SL., CASALI, AP. and AGOSTINHO, CA. 2003. Desempenho zootécnico e percentual de consumo de alimento de rã-touro (Rana catesbeiana) na fase de recria do sistema anfigranja. Revista Brasileira de Zootecnia, vol. 32, no. 3, p. 505-511.

McINTOSH, RD. 2000. Changing paradigms in shrimp farming: IV. Low protein feeds and feeding strategies. Advocate, vol. 3, no. 2, p. 44-50.

MENDONZA, GM., PATERIS, SE., ALE, CE., OTERO, MC., BÜHLER, MI. and NADERMACÍAS, MEF. 2012. Cultivable microbiota of Lithobates catesbeianus and advances in the selection of lactic acid bacteria as biological control agents in raniculture. Research in Veterinary Science, vol. 93, no. 3, p. 1160-1167. PMid:22695175. http://dx.doi. org/10.1016/j.rvsc.2012.05.007

MORAES, MAB., CARAMEL, BP., CARMO, CF., TABATA, YA., OSTI, JAS., ISHIKAWA, CM. and MERCANTE, CTJ. 2013. Dinâmica do fósforo em sistema intensivo de criação de trutas. In Anais do Reunião Cientifica do Instituto de Pesca, 2013. São Paulo: Instituto de Pesca. p. 263-265.

NAJIAH, M., LEE, SW., WENDY, W., TEE, LW., NADIRAH, M. and FAIZAH, SH. 2009. Antibiotic resistance and heavy metals tolerance in gramnegative bacteria from diseased American Bullfrog (Rana catesbeiana) cultured in Malaysia. Agricultural Sciences in China, vol. 8, no. 10, p. 1270-1275. http:// dx.doi.org/10.1016/S1671-2927(08)60338-7

OLVERA-NOVOA, MA., ONTIVEROS-ESCUTIA, VM. and FLORES-NAVA, A. 2007. Optimum protein level for growth in juvenile bullfrog (Rana catesbeiana Shaw, 1802). Aquaculture, vol. 266, no. 1-4, p. 191-199. http://dx.doi.org/10.1016/j. aquaculture.2007.02.013

PASTERIS, SE., GUIDOLI, MG., OTERO, MC., BÜHLERM, MI. and NADRE-MACÍAS, MEF. 2011. In vitro inhibition of Citrobacter freundii, a red-leg syndrome associated pathogen in raniculture, by indigenous Lactococcus lactis CRL 1584. Veterinary Microbiology, vol. 151, no. 3-4, p. 336-344. PMid:21531092. http://dx.doi.org/10.1016/j. vetmic.2011.03.025

PEREIRA, S., MERCANTE, CTJ., LOMBARDI, JV., OSTI, JAS. and MIASHIRO, L. 2008. Environmental characterization of pisciculture fishpond, São Paulo, Brazil. In Proceedings Symposium Brasil-Japão, 2008. São Paulo: SBPN Brazil Japan Researchers Association. p. 1-5.

SARTORY, E. and GROBELLAR, M. 1984. Extraction of chlorophyll $a$ from freshwater phytoplankton for spectrophotometric analysis. Hydrobiologia, vol. 114, p. 177-187. http://dx.doi.org/10.1007/BF00031869 
SEIXAS-FILHO, JT., NAVARRO, RD., SILVA, LN. and SOUZA, LN. 2011. Alimentaçẫo de girinos de râ-touro com diferentes níveis de proteína bruta. Ciência Animal Brasileira, vol. 12, no. 2, p. 250-256.

SEIXAS-FILHO, JT., NAVARRO, RD., GARCIA, SLR. and SANTOS, ACS. 2013. Regime alimentar de girinos de rã touro. Ciência Animal Brasileira, vol. 14, no. 1, p. 17-22.

SIPAÚBA-TAVARES, LHS. 1994. Limnologia aplicada à aquicultura. Jaboticabal: FUNEP. $70 \mathrm{p}$.

SIPAÚBA-TAVARES, LH., MORAIS, JCL. and De STÉFANI, MV. 2008. Comportamento alimentar e qualidade da água em tanques de criação de girinos de ră-touro Lithobates catesbeianus. Acta Scientiarum Animal Science, vol. 30, no. 1, p. 95-101.

SOKAL, RR. and ROHLF, J. 1995. Biometry: the principles and practice of statistics in biological research. 3rd ed. New York: W. H. Freeman and Company. $887 \mathrm{p}$.
STÉFANI, MV., MARACANTONIO, AS. and MARTINS, ML. 2001. Suplementaçáo com vitamina C e E sobre o desenvolvimento e sobrevivência de girinos de rã-touro (Rana catesbeiana Shaw, 1802). Ciência Rural, vol. 31, no. 5, p. 869-871. http:// dx.doi.org/10.1590/S0103-84782001000500021

STÉFANI, MV., NAKAGHI, LS. and URBINATI, EC. 2002. Alteraçôes estruturais do fígado da rã-touro (Rana catesbeiana, Shaw, 1802) submetida a dietas contendo diferentes níveis de carboidratos. Ars Veterinaria, vol. 18, no. 1, p. 78-82.

STRICKILAND, JDH. and PARSONS, TR. 1960. $A$ manual of sea water analysis. 2nd ed. Ottawa: Fisheries Research Board of Canada. 203 p. (Bulletin no 125).

TACON, AGJ. and FOSTER, IP. 2003. Aquafeeds and the environment: policy implications. Aquaculture, vol. 226, p.181-189. http://dx.doi.org/10.1016/ S0044-8486(03)00476-9

VALDERRAMA, JC. 1981. The simultaneous analysis of nitrogen and phosphorus total in natural waters. Marine Chemistry, no. 10, p. 109-122.

Received: 14 October 2013 Accepted: 17 April 2014 